$1-1-2000$

\title{
Fox Hunting, Pheasant Shooting and Comparative Law
}

\author{
Alan Watson \\ University of Georgia School of Law, wawatson@uga.edu \\ Khaled Abou El Fadl
}

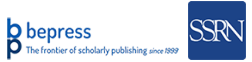

\section{Repository Citation}

Alan Watson and Khaled Abou El Fadl, Fox Hunting, Pheasant Shooting and Comparative Law (2000), Available at: https://digitalcommons.law.uga.edu/fac_artchop/665

This Article is brought to you for free and open access by the Faculty Scholarship at Digital Commons @ University of Georgia School of Law. It has been accepted for inclusion in Scholarly Works by an authorized administrator of Digital Commons @ University of Georgia School of Law. Please share how you have benefited from this access For more information, please contact tstriepe@uga.edu. 


\section{ALAN WATSON \& KHALED ABOU EL FADL}

\section{Fox Hunting, Pheasant Shooting, and Comparative Law}

When Herbert was gone he sat musing over his fire with Aby's letter still in his hand. A lawyer has always a sort of affection for a scoundrel, - such affection as a hunting man has for a fox. He loves to watch the skill and dodges of the animal, to study the wiles by which he lives, and to circumvent them by wiles of his own, still more wily. It is his glory to run the beast down; but then he would not for worlds run him down, except in conformity with certain laws, fixed by old custom for the guidance of men in such sports. And the two-legged vermin is adapted for pursuit as is the fox with four legs. He is an unclean animal, leaving a scent upon his trail, which the nose of your acute law hound can pick out over almost any ground. And the more wily the beast is, the longer he can run, the more trouble he can give in the pursuit, the longer he can stand up before a pack of legal hounds, the better does the forensic sportsman love and value him. There are foxes of so excellent a nature, so keen in their dodges, so perfect in their cunning, so skillful in evasion, that a sportsman cannot find it in his heart to push them to their destruction unless the field be very large so that many eyes are looking on. And the feeling is I think the same with lawyers.

Anthony Trollope, Castle Richmond (1860), chapter 39.

In the final appendix to his book, The Spirit of Roman Law ${ }^{1}$ Alan Watson, perhaps incautiously, drew a short analogy between the art of pheasant shooters in the U.K. and the art of the Roman jurists. Both are pastimes that are treated as important adjuncts of gentlemen. The Roman jurist as a gentleman in a slave-owning society where most work was despised had to fill in his day somehow. ${ }^{2}$ For historical reasons, interpretation of law had come to be one important

ALAN Watson is Ernest P. Rogers Professor of Law and Research Professor, University of Georgia.

Khaled ABou el Fadl is an Acting Professor of Law at UCLA School of Law. He is mainly responsible for the section on Islamic law: Watson bears primary responsibility for the rest.

1. The Spirit of Roman Law (1995), at $206 \mathrm{f}$.

2. Spirit, at $34 \mathrm{ff}$., especially $38 \mathrm{f}$. 
mark of a gentleman. Skill in interpretation by the rules they themselves developed brought the approbation of their fellows, and social prestige. For the Roman jurists, skill in interpretation was what counted. They were otherwise not much interested in law: not in winning court battles, not in devising court tricks and dodges, not in systematizing the law, not in law reform, not even in making the law the most practical and suitable for the society as a whole or for their section of it. For them there was no honor in that.

Olivia Robinson suggested to Watson that a better analogy than pheasant shooting would have been with fox hunting. Hence the quotation from Trollope. Trollope's hero at this point is a practicing attorney, very different from a jurist. But the jurist, too, sitting in his study, has the excitement of the chase, hunting for the interpretation that will stand up best, that can be fitted to various circumstances, and that will win the approval of his fellow jurists. The right solution to the legal problem is for him the fox. For the importance of fox hunting for a certain group of English society in the nineteenth century a cursory reading of Trollope is enough. ${ }^{3}$

Kenneth Pennington takes Watson to task for his picture of the Roman jurists. ${ }^{4}$ Professor Pennington writes:

Watson argues in his book that jurists can create a sophisticated legal system without looking beyond their own law. Law, he seems to argue, can be created by generations of subtle minds working out legal problems by using logic and elegant arguments that convince the profession. I do not believe that Roman jurists resembled Watson's, although I would concede that brilliant law can sometimes evolve in splendid isolation, cut off from outside influences and even separated from the needs and norms of society. But only occasionally. Most often law evolves under the sway of a myriad of influences. This truth is the best argument for studying legal history. ${ }^{5}$

This rather exaggerates Watson's view of the autonomy of law. And he sticks to his position. Watson has never argued (and never would) that the jurists were unaware of social, political and economic realities. They were, after all, men of the world: in the republic many sought (successfully) high public elected office; in the empire many

3. One short quotation from Orley Farm (1860-61) will suffice:

Foxes are vermin as well as rats, as Perry [a young gentleman keen on ratcatching] in his wickedness had remarked; but a young man who can break an old one's heart by a predilection for rat-catching may win it as absolutely and irretrievably by prowess after a fox. (chapter 14).

4. "The Spirit of Legal History," 64 U. Chi. L. Rev. 1097 (1997). He appears irritated by the analogy with pheasant shooters.

5. Spirit, at 1112. 
were top imperial legal bureaucrats. ${ }^{6}$ His claim was that typically the jurists refrained from using social, political and economic realities as an argument for their legal opinion; that often their reasoning was highly abstract, remote in appearance from these realities, and with a life of its own. ${ }^{7}$ Not only that, but Watson suggests that the Roman jurists were not unique in their approach. It corresponds to a pattern found elsewhere, in rabbinic law for instance and also in Islamic law.

The essentials for the pattern to come into existence are a system where:

(1) Law is created primarily by jurists, not by legislation or by judges.

(2) In their capacity as jurists, these individuals are largely independent of government, not state employees. Indeed, they operate outside of the state system.

(3) Their prestige, which is fundamental for their role, is independent of any job that they hold. It is determined by the approbation of those interested in those same matters. Pace Professor Pennington, being a Roman jurist was not a profession: they took no money for their services.

(4) The materials on which they work are usually older, regarded as authoritative, but are insufficient and require a great deal of interpretation.

The factors of the pattern are:

(1) The opinions of the jurists are not law. It is their acceptance that makes law. Thus, there is wide scope for differing opinions.

(2) The opinions give the impression that the jurists are talking to one another; not, as with judges, to a wider audience; or, as with legislation, to the public at large.

(3) Jurists often give no reasons for their opinions; or if they did the reasons are not recorded in our source materials. At times what gives opinions any authority they have is the reputation of the individual jurist.

(4) They develop a style of reasoning that is most marked by the kind of arguments they do not use. Thus, they do not much appeal to utility, ${ }^{8}$ public usefulness, seldom to fairness or justice.

(5) Many of their decisions and arguments appear to the outsider to be remote from reality. No doubt the jurists are usually aware of social realities but that awareness often does not appear.

6. For the careers of jurists see, above all, Wolfgang Kunkel, Herkunft und soziale Stellung der römischen Juristen ( $2^{\text {nd }}$ ed. 1967).

7. For a chapter in Spirit, specifically devoted to the jurists struggling with realities at the expense of legal principle see $98 \mathrm{ff}$.

8. Pace Pennington, Spirit, at 1113. 
They are so immersed in their own technique that they give opinions that to outsiders look absurd, at times callous.

(6) So involved are they with their techniques that they discuss at length issues that the outsider would regard as trivial. They also discuss situations that we can scarcely imagine would ever arise. In this regard jurist-made law diverges greatly from judge-made law. Judges' discussions concern live situations, and at the level at which the judges make law the situations are not trivial.

(7) In appearance at least, the jurists are not much interested in law reform.

(8) They seldom show interest in making the law systematic.

(9) The success of a jurist's opinions is often posthumous, even when social conditions have changed.

As with the analogy of pheasant shooters and Roman jurists, the parallels are not complete in the legal systems that are here adduced. Above all, Roman law is a secular, and rabbinic and Islamic law are religious systems. And religious law is a search for fundamental truth. ${ }^{9}$ Still, a common pattern does emerge.

\section{RABBINIC LAW ${ }^{10}$}

The work that will concern us in this section will be the Mishnah, the main source of rabbinic law in its most formative days, and which was compiled around 220 A.D. It is above all a compilation of the opinions of earlier rabbis. It is admitted on all sides that it presents a one-sided view of the Judaism of the period, but that is not our concern. Our business is with it as a law book or book of laws giving the viewpoint and attitude of the rabbis. ${ }^{11}$ A statement of Jacob Neusner is very relevant:

Falling into the hands of someone who has never seen this document before, the Mishnah must cause puzzlement. From the first line to the last, discourse takes up questions internal to a system that is never introduced. The Mishnah provides information without establishing context. It presents disputes about facts hardly urgent outside a circle of faceless disputants. Consequently, we start with the impression that we join a conversation already long under way about topics we can never grasp anyhow. Even though the language is our own, the substance is not. We shall feel as if we are in a transit lounge at a distant airport. We understand the words people say, but we are baffled by their

9. Still, the jurists had their origin in the College of Pontiffs; Watson, Spirit, at $34 \mathrm{ff}$.

10. For what follows on rabbinic law we are much indebted to Steven F. Friedell.

11. See, e.g., Shaye J.D. Cohen, "Judaism to the Mishnah: 135-220 C.E.," in Christianity and Rabbinic Judaism, Hershel Shanks (ed.) (1992), 195ff. 
meanings and concerns, above all, by the urgency in their voices: What are you telling me? Why must I know it? Who cares if I do not? ${ }^{12}$

At the beginning we will set out some texts to show the approach of the rabbis. We will choose first examples from the tractate Shabbat ("The Sabbath") to illustrate the richness of the material. God had ordered that no work should be done on the Sabbath:

Exodus 20.8. Remember the sabbath day, and keep it holy. 9. Six days you shall labor and do your work. 10. But the seventh day is a sabbath to the Lord your God; you shall not do any work - you, your son or your daughter, your male or female slave, your livestock, or the alien resident in your towns. 11. For in six days the Lord made heaven and earth, the sea, and all that is in them, but rested the seventh day; therefore the Lord blessed the sabbath day and consecrated it.

Deuteronomy 5.12. Observe the sabbath day and keep it holy, as the Lord your God commanded you. 13. Six days you shall labor and do all your work. 14. But the seventh day is a sabbath to the Lord your God; you shall not do any work - you, or your son or your daughter, or your male or female slave, or your ox or your donkey, or any of your livestock, or the resident alien in your towns, so that your male and female slave may rest as well as you. 15. Remember that you were a slave in the land of Egypt, and the Lord your God brought you out of there with a mighty hand and an outstretched arm; therefore the Lord your God commanded you to keep the sabbath day.

But God failed to say what work was. The rabbis had to resort to interpretation. Thus we have in M. Shabbat 7.2:

A. The generative categories of acts of labor [prohibited on the Sabbath] are forty less one:

B. (1) he who sows, (2) ploughs, (3) reaps, (4) binds sheaves, (5) threshes, (6) winnows, (7) selects [fit from unfit produce or crops], (8) grinds, (9) sifts, (10) kneads, (11) bakes;

C. (12) he who shears wool, (13) washes it, (14) beats it, (15) dyes it;

D. (16) spins, (17) weaves,

E. (18) makes two loops, (19) weaves two threads, (20) separates two threads;

F. (21) ties, (22) unties,

12. The Mishnah xiii (1988). 
G. (23) sews two stitches, (24) tears in order to sew two stitches;

H. (25) he who traps a deer, (26) slaughters it, (27) flays it, (28) salts it, (29) cures its hide, (30) scrapes it, and (31) cuts it up;

I. (32) he who writes two letters, (33) erases two letters in order to write two letters;

J. (34) he who builds, (35) tears down;

K. (36) he who puts out a fire, (37) kindles a fire;

L. (38) he who hits with a hammer; (39) he who transports an object from one domain to another one. ${ }^{13}$

M. lo, these are the forty generative acts of labor less

We start with this text primarily because it shows the scope there often is for interpretation in a system where jurists are the prime law-makers. But, despite its importance, the text is for us only a beginning in understanding the prohibitions against work on the Sabbath. After all, what is "reaping?" - which is not defined. Was plucking a few heads of grain "reaping?"14 And transporting an object from one domain to another was forbidden, but what counts as an "object?" The issue is much discussed in the tractate. But if the text is a beginning - and it can be nothing more - why is it so unsystematically placed so far into the tractate as 7.2? And why is there such a difference in specificity between one prohibition and another? "He who sews" appears again as "sews two stitches." Dealing with a trapped deer merits 7 out of the 39 prohibited clauses. And can an outsider, even a Jew of the less observant, regard as anything but trivial the provisions that one may not sew two stitches or tear in order to sew two stitches? One, but not two? And why is walking beyond a certain distance not listed here as prohibited?

Our main points with this text are (1) the wide scope available to jurists - rabbis - for interpretation; (2) a certain lack of systematization; (3) the appearance to outsiders of some degree of triviality; (4) a sense to the outsider of some arbitrariness. We have, however, produced the text as a backdrop to a few others. Thus, M. Shabbat 1.1:

A. [Acts of] transporting objects from one domain to another [which violate] the Sabbath

(1) are two, which [indeed] are four [for one who is] inside,

13. The translation like all others here from the Mishnah is that of Jacob Neusner, The Mishnah.

14. See Mark 2.23f;; Philo De Vita Mosis 2.22 (not permitted to cut any shoot or branch, or even a leaf or to pluck any fruit): for later evidence see Jerusalem Talmud Sabbet 9c. Cf. Hermann L. Strack \& Paul Billerbeck, Kommentar zum Neuen Testament aus Talmud und Midrasch 1, 615ff. (5th ed. 1969). 
(2) and two which are four [for one who is] outside.

B. How so?

I C. [If on the Sabbath] the beggar stands outside and the householder inside,

D. [and] the beggar stuck his hand inside and put [a beggar's bowl] into the hand of the householder,

E. or if he took [something] from inside it and brought it out,

F. the beggar is liable, the householder is exempt.

II G. [If] the householder stuck his hand outside and put [something] into the hand of the beggar, inside.

$\mathrm{H}$. or if he took [something] from it and brought it

I. The householder is liable, and the beggar is exempt.

III J. [If] the beggar stuck his hand inside, and the householder took [something] from it,

$K$. or if [the householder] put something in it and he [the beggar] removed it,

L. both of them are exempt.

IV M. [If] the householder put his hand outside and the beggar took [something] from it,

$\mathrm{N}$. or if [the beggar] put something into it and [the householder] brought it back inside,

$O$. both of them are exempt.

This we quote because it is the very first text in the tractate. It deals with a very particular aspect of one of the 39 prohibitions of working on the Sabbath, namely carrying objects from one domain to another. In a systematic work we would have expected M. Sanhedrin 7.2 to have been placed at this point, and the present text to appear much later. To continue with lack of system: the following text M. Shabbat 1.2 deals with a very different subject, behavior shortly before the afternoon prayer. We are not being unhistorical in pointing out the lack of systematization: many texts from the ancient world are systematic.

The text also has the air of being remote from reality. The issue seems trivial, could scarcely come to court, and not an issue of social concerns. But clearly it occupied the rabbis in their search for the rules that were implied in God's law. One should notice the plight of the beggar: He can scarcely receive alms, even of food, without sinning or causing his donor to sin. He could not receive outside because of the prohibition against carrying. This, indeed, is probably the context of our text.

M. Shabbat 1.4-8 are concerned specifically with questions that were a matter of dispute between the School of Shammai and the School of Hillel, both of which had been founded in the mid-first cen- 
tury. ${ }^{15}$ Many others refer to disputes among the scholars. Thus, $\mathrm{M}$. Shabbat 6.8:

A. "A cripple [lacking a leg] goes forth with his wooden stump," the words of R. Meir.

B. And R. Yose prohibits it.

C. And if it has a receptacle for pads, it is susceptible to uncleanness.

D. His kneepads (1) are susceptible to uncleanness imparted by pressure [to something upon which a $Z a b$ may lie or sit], (2) they go forth with them on the Sabbath, and (3) they go into a courtyard with them.

E. His chair and its pads (1) are susceptible to uncleanness imparted by pressure, (2) they do not go out with them on the Sabbath, and (3) they do not go in with them into a courtyard.

F. An artificial arm is insusceptible to uncleanness, and they do not go out in it.

God had also forbidden the working of animals on the Sabbath, so the prohibition on going out of the domain with an object also became an issue with regard to them, and section 5 is devoted to this. Thus, 5.4:

(1) An ass does not go out with its saddle cloth when it is not tied to him,

B. or with a bell, even though it is plugged,

C. or with the ladder yoke around its neck,

D. or with a strap on its leg.

E. And (2) fowl do not go forth with ribbons or straps on their legs. fat tail.

F. And (3) rams do not go forth with a wagon under their

G. And (4) ewes do not go forth protected [with the wood chip in their nose].

H. And (5) a calf does not go out with its rush yoke.

I. or (6) a cow with a hedgehog skin [tied around the udder], or with a strap between its horns.

J. The cow of R. Eleazar b. Azariah would go out with a strap between its horns,

$K$. not with the approval of the sages.

The ribbons and straps on fowls' legs were marks of identification. Rams' fat tails were highly prized, and the wagon was to protect them from the ground. The wood chip in ewes' noses was to make them sneeze and expel worms. The rush yoke was a training device.

15. See, e.g., Lee I.A. Levine in Christianity and Rabbinic Judaism 132 (1992). 
And the hedgehog skin on the cow's udder was to prevent the milk being drained by other creatures.

In all the texts looked at so far, the acceptability of the ruling depends on the authority of the jurist. That is quite typical. Presumably at the time the rabbis would give arguments for their opinions. If so, the arguments have been cut out as not significant. Occasionally, but less frequently a biblical text may be cited as authority, and further argument given. Thus, M. Shabbat 6.4:

A. A man should not go out with (1) a sword, (2) bow, (3) shield, (4) club, or (5) spear.

B. And if he went out, he is liable to a sin offering.

C. R. Eliezer says, "They are ornaments for him."

D. And sages say, "They are nothing but ugly,

E. "since it is said, And they shall beat their swords into plowshares and their spears into pruning hooks; nation shall not lift up sword against nation, neither shall they learn war any more (Is. 2:4)."

F. A garter is insusceptible to uncleanness, and they go out in it on the Sabbath.

G. Ankle chains are susceptible to uncleanness, and they do not go out in them on the Sabbath.

A man could go out wearing his normal clothing, including his habitual adornments. In our text it appears that a garter is permissible, presumably as a normal adjunct to clothing. No argument, it seems, needs to be expressly set out. But there was a dispute over a man going out with a sword or a bow or a shield or a club or a spear. For Rabbi Eliezer, he could so go out because these items counted as adornments, and it was permitted to go out wearing one's usual ornaments. The Sages not only gave the opposite ruling but they used a different approach. They did not (so far as the text goes) discuss whether these items constituted ornaments or weapons - carrying of weapons on the Sabbath was forbidden - or the circumstances in which they constituted one or the other. Instead the Sages cited Isaiah 2.4. Presumably the argument from that verse was that swords, spears, and other such implements always had an element of the improper, so it was irrelevant whether they were adornment on the Sabbath or not.

From the examples so far adduced, all from M. Shabbat, we see that the systematics could be weak; conflicting opinions might result in no clear decision, and that rabbinical opinion, resulting from their own juristic reasoning could appear to be independent of issues of social, political or economic benefits. We are, of course, not asserting that the rabbis were unaware of these issues: only that, as with the Roman jurists, the tradition of legal interpretation could take precedence. The jurists needed the approval of their fellows. 
Another example of what appears as unsystematic treatment is M. Gittin ("Bills of Divorce"). It begins (1.1) with the issue of an agent bringing a bill of divorce from outside Israel to a wife in Israel. Only in the very last section (9.10) do we learn the grounds of divorce.

The three tractates most seemingly involved with secular concerns or that deal with damages are: M. Baba Qamma ("The First Gate"), M. Baba Mesia ("the Middle Gate"), and M. Baba Batra ("The Last Gate"). They show the same approaches as appeared in M. Shabbat. We will give a few illustrations from Baba Mesia which treats lost property, guardianship, usury, and the hire of laborers. The opening text (1.1) (which need not be quoted) is again not concerned with a fundamental issue but with a detail: in court two men both claim to be the finders of a cloak. How is a decision to be reached? A common opinion is that the three "Gates" were originally one unit. In that case, the issue of systematization would be slightly different, though its lack would still be significant. It would be explicable, but still surprising, that M. Baba Mesia 1.1 appears where it does. There would seem to be no interest in a rearrangement. Subsequently other issues arise: M. Baba Mesia 3.9:

A. He who deposits a jar with his fellow,

B. and the owner did not specify a place for it,

C. and [someone] moved it and it was broken -

D. if in the midst of his handling it, it was broken,

E. [and if he moved it to make use of it] for his own needs, he is liable.

F. [If he moved it] for its needs, he is exempt.

G. If after he had put it down, it was broken.

$H$. whether he had moved it for his own needs or for its needs, he is exempt.

I. [If] the owner specified a place for it,

$J$. and [someone] moved it and it was broken -

$\mathrm{K}$. whether it was in the midst of his handling it or whether it was after he had put it down.

L. [if he had moved it] for his own needs, he is liable.

M. [But if he had moved it] for its needs, he is exempt.

The text concerns what in Roman law would be the contract of deposit. But the Mishnah does not use here the technical concept of fraud which decided liability in Roman law. Nor indeed is negligence the issue. ${ }^{16}$ Instead the rabbis think in terms of various factual situations and determine liability thereby. The depositee could be liable even without negligence on his part. The practical problem is that

16. Negligence as a concept is either missing or insignificant in rabbinic law. 
this would make it more difficult for someone in time of need ${ }^{17}$ to find someone to look after his goods.

Again M. Baba Mesia 4.11:

A. They do not commingle one sort of produce with another sort of produce,

B. even new and new [produce, plucked in the same growing season],

C. and it goes without saying, new with old.

D. To be sure, in the case of wine they had permitted commingling strong with weak,

E. because it improves it.

Presumably the ultimate - we stress ultimate - origin of the basic rule is the biblical prohibition on the mixing of kinds. Thus, Deuteronomy 22.9ff:

9. You shall not sow your vineyard with a second kind of seed, or the whole yield will have to be forfeited, both the crop that you have sown and the yield of the vineyard itself.

10. You shall not plow with an ox and a donkey yoked together.

11. You shall not wear clothes made of wool and linen woven together.

Leviticus 19.19.

You shall keep my statutes. You shall not let your animals breed with a different kind; you shall not sow your field with two kinds of seed; nor shall you put on a garment made of two different materials.

The biblical prohibition itself could never have been fully applied. Mules, bred from a mare by a donkey, are a prime example. ${ }^{18}$ And several Biblical texts show that God's law was often ignored even by Jacob and the priests. ${ }^{19}$ Yet it is here seemingly applied, as if by very strict reasoning, to a very different situation: the mixing of fruits for sale. Yet there is a concession to practical utility: strong wine may be mixed with weak. It is possible, even probable, that the rabbis had a practical purpose: to prevent fraud by a seller who included not so good fruit with good fruit. Our text, M. Baba Mesia 4.11, is one of a series in M. Baba Mesia 4 that is concerned with hindering over-

17. And, almost by definition, a depositor is someone in time of need.

18. Ezekial 12.14 is no evidence to the contrary, pace e.g., Roland K. Harrison; The International Standard Bible Encyclopedia 3, Geoffrey W. Bromiley, et al. (eds.) (1986), 430. Ezekial is listing Israel's trading partners and includes: "Beth-togarmah exchanged for your wares horses, war horses, and mules." There is no indication that the mules were imported because their breeding among Jews was prohibited: that of horses and war horses, also imported, was not.

19. See Calum Carmichael, The Spirit of Biblical Law 50 (1996). 
reaching. ${ }^{20}$ If so, then it is traditional reasoning that inhibits a more flexible approach.

Our next text relates to the prohibition on usury. God's express ruling is in Deuteronomy 23.19:

You shall not charge interest on loans to another Israelite, interest on money, interest on provisions, interest on anything that is lent. 20. On loans to a foreigner you may charge interest, but on loans to another Israelite you may not charge interest, so that the Lord your God may bless you in all your undertakings in the land that you are about to enter and possess.

Hence M. Baba Mesia 5.2

A. He who lends money to his fellow should not live in his courtyard for free.

B. Nor should he rent [a place] from him for less [than the prevailing rate],

C. for that is [tantamount to] usury.

D. One may effect an increase in the rent charge [not paid in advance], but not the purchase price [not paid in advance].

E. How so?

F. [If] one rented his courtyard to him and said to him, "If you pay me now [in advance], lo, it's yours for ten selas a year,

G. "but if [you pay me] by the month, it's a sela a month"

$\mathrm{H}$. it is permitted.

I. [But if] he sold his field to him and said to him, "If you pay me the entire sum now, lo, it's yours for a thousand $z u z$.

J. "But if you pay me at the time of the harvest, it's twelve maneh $[1,200 \mathrm{zuz}]$, , -

$\mathrm{K}$. it is forbidden.

The whole subject of usury is one of abstruse reasoning. Our main concern is with the distinctions at the end of the text. If payment for the lease was either for ten selas per year or one sela per month [i.e., twelve selas per year] the lessor was not a usurer, and the bargain was not prohibited. If by a different arrangement in sale the price was of a thousand $z u z$ if paid at once, one thousand two hundred $z u z$ if payment was delayed to harvest time the seller was a usurer and the transaction was prohibited. But in practical, moral, social and economic terms there is not any real difference. More than that, from a different standpoint we can have very different results for the first

20. See the interpretation in Rosh.4.23; Shulhan Anukh Hoshen Mishpat 228.10. 
transaction. In it the lessor receives the twelve month rent - now set at ten - in advance, and has the use of the money for a year. In practical terms he has the practical advantages of a usurer. The only difference is that in money he receives less. In fact, as the text stands the basic arrangement would be for payment for a year in advance. But in a sense the lessee is even more a usurer. If he takes the basic agreement he pays ten selas, and the two not to be paid look suspiciously like interest on the money paid in advance.

Then, still on usury, we may look at M. Baba Mesia 5.9:

A. A man should not say to his fellow, "Lend me a kor of wheat, and I'll pay you back [a kor of wheat] at threshing time."

B. But he says to him, "Lend it to me until my son comes [bringing me wheat],"

C. or, ". . . until I find the key."

D. Hillel prohibits [even this procedure].

E. And so does Hillel say, "A woman should not lend a loaf of bread to her girl friend unless she states its value in money.

F. "For the price of wheat may go up, and the two women will turn out to be involved in a transaction of usury."

Our main interest is in the loan of a loaf of bread. The issue for an outsider is essentially trivial. The idea of legal proceedings is out of the question. Moreover, the situation would never arise. No woman lending a loaf to a woman friend would state its value in money. That is beyond the boundary of friendship. Even more than that, Hillel bases his absolute prohibition on a possibility: the price of wheat might go up. ${ }^{21}$ There are no social or moral values in Hillel's approach. And the relationship of the ruling to the original prohibitions on usury are remote in the extreme. ${ }^{22}$

We now turn to an example from the very different rules of God on foraging, in Deuteronomy 23.24f.

If you go into your neighbor's vineyard, you may eat your fill of grapes, as many as you wish, but you shall not put any in a container. 25. If you go into your neighbor's standing grain, you may pluck the ears with your hand, but you shall not put a sickle to your neighbor's standing grain.

Again the rabbis' extensive interpretation is in line with previous examples that we have produced. Thus M. Baba Mesia 7.2:

A. And these [have the right to] eat [the produce on which they work] by [right accorded to them in] the Torah:

21. What if it went down?

22. M. Baba Mesia 5.10 could equally be used in this connection. 
B. he who works on what is as yet unplucked [may eat from the produce] at the end of the time of processing;

C. [and he who works] on plucked produce [may eat from the produce] before processing is done;

$D$. [in both instances solely] in regard to what grows from the ground.

E. But these do not [have the right to] eat [the produce on which they labor] by [right accorded to them in] the Torah:

F. he who works on what is as yet unplucked, before the end of the time of processing;

G. [and he who works] on plucked produce after the processing is done,

$\mathrm{H}$. [in both instances solely] in regard to what does not grow from the ground.

7.3 A. [If] one was working with his hands but not with his feet,

B. with his feet but not with his hands,

C. even [carrying] with his shoulder,

D. lo, he [has the right to] eat [the produce on which he is working].

E. R. Yose b. R. Judah says, "[He may eat the produce on which he is working] only if he works with both his hands and his feet."

7.4 A. [If the laborer] was working on figs, he [has] not [got the right to] eat grapes.

B. [If he was working] on grapes, he [has] not [got the right to] eat figs.

C. But [he does have the right to] refrain [from eating] until he gets to the best produce and then [to exercise his right to] eat.

D. And in all instances they have said [that he may eat from the produce on which he is laboring] only in the time of work.

E. But on grounds of restoring lost property to the owner, they have said [in addition]:

F. Workers [have the right to] eat as they go from furrow to furrow [even though they do not then work],

G. and when they are coming back from the press [so saving time for the employer];

$\mathrm{H}$. and in the case of an ass [nibbling on straw in its load], when it is being unloaded.

The rabbis have limited the law about travelers to laborers in the field. This caused further exhaustive interpretation. Thus, for instance the laborer could eat the produce on which he had worked at the time of processing. If he worked on grapes he could not eat figs, 
but he can hold his hunger till he comes to the best grapes. He can eat in this way only when actually working, but this includes the time spent in going from furrow to furrow. This is a fringe benefit. ${ }^{23}$ In the light of what we have said above, no further commentary by us is needed.

One further topic, and only one part of it, needs discussion, namely the treatment of pledge debtors. God's rules are set out in Deuteronomy 24.6-17. Part of verse 17 reads: "You shall not take a widow's garments in pledge." This is treated in part of M. Baba Mesia 9.13: "From a widow, rich or poor, they do not take a pledge." From the wording of Deuteronomy "widow's garments" are interpreted as meaning any property of widows. Such extensive interpretation of a legal provision is common in many societies. But the practical social and economic consequence of the interpretation, not obviously implicit in Deuteronomy, is that it will be much harder for a widow, even a wealthy widow to obtain a loan.

Medieval rabbis and Jewish community leaders understood the impracticality of much of the law in the Mishnah. The Rashba ( $R$. Solomon ben Abraham Adret who lived in Barcelona around 12351310) wrote in a responsum that if cases of personal injuries and similar matters were decided according to Torah law, the world would be destroyed. ${ }^{24}$ Subsequently the Ran (Rabbi Nissim ben Reuben Gerondi who lived circa 1310-1375) accepted that some Gentile societies had law better suited than the Torah to the social order. For him the Torah law is designed to serve a religious purpose, not to improve the social order. ${ }^{25}$

\section{ROMAN LAw}

No one, we believe, will conclude from the preceding section that we are critical of the rabbis' stance. Indeed, the aim is to show that it belongs to an overrarching pattern. No one, we hope but with less optimism, will imagine that we think the rabbis were unaware of political, economic and social considerations. Only, these are not stressed. Our real claim is that the rabbis focused on interpretation according to their own canons. Of course, religion was there as the foundation, but often the situation discussed is so far distant from the circumstances of the biblical law that the connection can scarcely be seen.

When we come now to development by jurists of Roman law, and wish to claim a pattern with development of rabbinic law we must

23. See B. Bava Mezia 85b. Professor Friedell calls to our attention Rabbi Menahem Meiri's (1249-1316) comment: "The learned based on tradition that this matter only applies to a hired worker. If not so, how would he have permission to enter."

24. Responsa Rashba 3.393.

25. Derashot. 
insist that a similar pattern does not mean identity. To avoid misunderstandings we list at the outset factors which constitute real differences between the juristic development of rabbinic law and of Roman law.

First, rabbinic law is religious, Roman law is secular. Accordingly, rabbis will be more concerned with minute details and with what appears to outsiders as trivia than will Roman jurists. ${ }^{26}$ Second, the ultimate source of rabbinic law was the Torah. But after this there was no or little ${ }^{27}$ subsequent legislation nor any other source of law but learned interpretation. At Rome, though after the Twelve Tables of the mid-fifth century legislation was always uncommon, it continued until the emperor Claudius (41-54). In addition, law was in effect made by the Edicts of the praetors - the high elected officials who controlled the courts - until the time of Hadrian (117-138). Further, senatus consulta, decrees of the senate, came to have the force of law; and there could always be rulings of various kinds on law by the emperors. So, for the jurists, there could be more modern "official" law that could cut down the scope of interpretation.

Third, there was no official way in rabbinic law to settle what the law was. Things were rather different at Rome when Augustus gave the ius respondendi. Gaius writes of it: ${ }^{28}$

The answers of the learned are the decisions and opinions of those who are authorized to lay down the law. If the decisions of all of them agree, what they do hold has the force of lex, but if they disagree, the judge is at liberty to follow whichever decision he pleases. This is declared by a rescript of the late emperor Hadrian.

The exact nature of this right which appears also - in a rather different form - in D.1.2.2.49, is disputed but that need not concern us here. ${ }^{29}$ The ius respondendi so long as it lasted - not all that long would still not restrict the power of interpretation. And in many situations what the law was would remain uncertain.

Fourth, the jurists, but not the rabbis, were concerned with interpreting the law of the state which always had ultimate control. That control, though, was often not used.

Fifth, the leading Roman jurists were involved in public life, though not in their capacity as jurists. Many that we know of in the republic were consuls or praetors or pontiffs. ${ }^{30}$ Many in the empire

26. For the importance of emphasis on trivia in law see Alan Watson, Ancient Law and Modern Understanding (1998), 71ff.

27. There is for example the notorious chauvinistic measures of the synod of Hillelites and Shammaites of 65 or 66 : M. Niddah 4.1; Babylonian Talmud Shabbat $16 \mathrm{~b}$. 28. G.1.7.

29. For one view see Alan Watson, Sources of Law, Legal Change, and Ambiguity 6ff. (2d ed. 1998).

30. See above all the details in Kunkel, Herkunft. 
were imperial bureaucrats including the great Ulpian, Paul, and Papinian. But we emphasize that in their writings as jurists they were not functionaries. Rabbinical scholars were in different case, Certainly some of those cited in the Mishnah served as Presidents of the Rabbinical Council or Sanhedrin: ${ }^{31}$ Hillel the Elder, Simeon ben Gamaliel I, Gamaliel II, Simeon ben Gamalliel II, Judah the Patriarch, and Gamaliel III, but that was the result of being a rabbi. Of these, only Gamaliel II, Simeon ben Gamalliel II, and Judah the Patriarch are cited frequently.

Sixth, as a result of past history, the interest of Roman jurists centered on what we would call private law. This last point demands further explanation which will also be important subsequently for our understanding of this section. The ancient Twelve Tables resulted from a conflict for legal equality between the plebeians and the patricians: the latter had a monopoly of state offices. In the result the codification was a victory for the patricians who included in the code only those rules they were willing to share with plebeians. Thus, no public law or sacred law. The Twelve Tables contain to the greatest extent private law. The patricians then gave a monopoly of interpretation to the College of Pontiffs, the most important religious body, and it appointed one of its number each year to interpret the code. Hence, it became important for Romans who wished to rise high in public office to be skilled in interpreting the law. But only interpretation. And at that, interpretation of private law. It is this concentration on private law and its separation from public and religious law that makes Roman law look so different from Rabbinic and Islamic law. ${ }^{32}$

When we come now specifically to the work of the Roman jurists, our first topic must be the lack of systematization. On this we will say very little. Systematization is notoriously bad as set out in Justinian's Digest and Code, and we would be simply repeating what Watson has already written in The Spirit of Roman Law. It is enough to recommend the reader to look at the books and titles of the Digest as they are set out in the table of contents of that work. The great 19th century German scholar, Theodor Mommsen, wrote "Diese Ordnung oder Unordnung ist die des julianischen Edicts." 33 ("This order or disorder is that of the Julianic Edict.") And the Edict had grown up piecemeal, and haphazardly. ${ }^{34}$ The great work of the rightly celebrated French jurist, Jean Domat (1625-1696), is properly entitled Les Loix civiles dans leur ordre naturel ("The Civil Laws in their Natural Order"). This is largely an attempt to set out French

31. See Herbert Danby, The Mishnah 799f. (1933).

32. For details, see Watson, Spirit, 33ff., 44ff.

33. Juristische Schriften 1, 164 (1905).

34. See, above all, Otto Lenel, Das Edictum Perpetuum (3rd. ed. 1927). 
law with a Roman law base. But the very title, as indeed the book itself, shows his dissatisfaction with the Roman arrangement. In the following century, his famous compatriot, Robert Joseph Pothier (1699-1772) produced an edition of the Digest, his Pandectae Justinianae. In this, although the books and titles remain unchanged, the texts within each title are moved around in an attempt to make each topic more comprehensible. So far as we are aware, no one has ever praised the arrangement of the Digest. We stress this lack of systematization which is endemic in Roman juristic writing because it is precisely jurists, qua jurists, who have the best possibility of making law systematic. Judges, faced with one case after another, cannot do it. In fact, one Roman jurist, only one, Gaius, produced a system, and that has come to dominate modern codified law. But he was treated as so unimportant that "Gaius" is the only part of his name that we know, his system was not followed by other Roman jurists, who refer to him only once-and even that reference is doubted. ${ }^{35}$ The great, powerful subsequent jurists, Ulpian, Paul, Papinian and others, continued on their merry way with little systematization. This we see in the huge, separate commentaries on edictal law and civil law of Ulpian and Paul, when there was only one court system!

On jurists' interest in reform we can say little, because there was little. The best evidence for that proposition is Justinian's Quinquagintae Decisiones, "The Fifty Decisions." These imperial rulings were issued after the promulgation of the first Code and some apparently even after the beginning of work on the Digest, ${ }^{36}$ the compendium and abridgement of juristic writings. They are an attempt to give a precise answer to problems that had confronted classical jurists but were not solved by them. Yet from the emperor Augustus onwards, most of the famous jurists were top civil servants. Any of them could have solved any of these issues by an imperial ruling. But they were not interested. One example may stand for all. The Twelve Tables of the mid-fifth century B.C. distinguished manifest theft from non-manifest theft, but it did not explain what each was. Hence, there was scope among the jurists for disagreement. Thus, Gaius, writing in the mid-second century can write at G. 3.184f.:

Manifest theft, according to some, is theft detected whilst being committed. Others extend it to theft detected in the place where it is committed, holding, for example, that a theft of olives committed in an olive-grove, or of grapes committed in a vineyard, is manifest if detected whilst the thief is still in the olive-grove or vineyard, or, where there is theft in a house, whilst the thief is still in the house. Others, go-

35. See, e.g., Watson, Spirit, at $201 \mathrm{ff}$.

36. See, e.g., W.W. Buckland, Textbook of Roman Law 46 (3d ed. by P. Stein 1963). 
ing further, have maintained that a theft remains manifest up to when the thief has carried the thing to the place he intended. And others go so far as to say that it is manifest if the thief is seen at any time with the thing in his hands. This last opinion has not been accepted, nor does the opinion that the theft is manifest if detected before the thief has carried the thing to where he intended, seem to be approved, because it raises a considerable doubt as to whether this is to be limited to one day or extends to several, the point being that thieves often intend to carry off what they have stolen to another town or province. Either of the first two opinions is tenable, but the second is generally preferred.

The position was not clarified even in the time of Justinian almost four centuries later. Thus, D.47.2.3:

A thief is manifest whom the Greeks describe as ' $\varepsilon \pi$ '

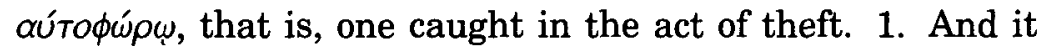
makes little difference whether he be caught by the owner of the thing or by someone else. 2. But is a thief manifest only if he be caught in the act or also if he be apprehended elsewhere? The better view is that which appears in the writings of Julian, that is to say, that although he be not taken at the scene of the offense, he will still be a manifest thief if he be taken with the stolen thing, before he has taken it to its intended destination.

D.47.2.4. "Destination," for this purpose, means "the place where he aimed to remain that day with the stolen thing." D.47.2.5. Consequently, whether he be apprehended in a public place or in a private one, before he gets the thing to its intended resting place, he is in such a case that he will be a manifest thief, if caught with the stolen goods; so wrote Cassius. 1. But if he should have reached his destination, then, although he later be found with his booty, he will not be a manifest thief.

But the matter was important for the penalty. The manifest thief was condemned to pay four times the value of what was stolen, the non-manifest thief only double. Nor can it be claimed that the distinction was meaningless because thieves usually have no money. Many Roman thieves would be slaves, and then it would be their owner who had to pay the penalty.

Professor Pennington misleadingly tells us. "But we do know that the jurists retained their status for centuries, altering their opinions on the basis of justice (equitas) and utility (utilitas), not just elegant argument." 37 Alas, not so. Of course, jurists disagreed -

37. Spirit, at 1113. 
what, otherwise is the interest? - and offered different approaches. But reform, in the sense of making "better," or "more socially beneficial" law? Let us take the case of utility (utilitas).

The word utilitas is frequent in the Digest. ${ }^{38}$ But only eight texts report that a juristic ruling is propter utilitatem, "on account of utility." And these texts divide into three classes. First, two texts relate that some rule "has been accepted on the ground of utility." 39 That is, the jurist writing the text is not himself arguing for a proposition on the ground of utility. Second, two texts record that a view is generally held on the ground of utility. ${ }^{40}$ Again, the jurist is not arguing his own view on the ground of utility. Only four show in any way a jurist arguing for his own proposition "on the ground of utility." 41 One text next records that favore utilitatis, "for the benefit of utility," a proposition was adduced - again usefulness is not the argument of the writer of the text. Utilitatis causa, "on account of usefulness," occurs only fourteen times in the Digest. Of these thirteen relate that a rule was accepted or is accepted or a remedy was introduced on the ground of utility. ${ }^{42}$ Not one of these thirteen shows jurists arguing or "altering their opinions on the basis of . . utility." One text, D.46.3.95.7, relates that Labeo and Pegasus thought a ruling should be accepted on the ground of utility. Whether they used utility as an argument or whether the writer of the text, Papinian, is attributing that argument to them is not entirely clear. Five texts have utilitatis gratia, "in the interest of utility." Four of these report this as the reason that influenced the jurist. ${ }^{43}$ No other Digest text is relevant to the present discussion.

What the texts show is first that the jurists could be aware that a remedy was introduced or a rule adduced on the ground of utility. Who would ever doubt that? Second, and more importantly for us, they show that utility was not an argument that a jurist would produce to bolster his own opinion. It was not the kind of argument that would appeal to his fellow jurists. What we hope we have shown with regard to utilitas applies equally to aequitas. ${ }^{44}$

Our claim, of course, has never been that the Roman jurists were unaware of social reality:45 only that, like the rabbis, they not infrequently gave precedence to elegant, legalistic argument, preferring a

38. See Vocabularium Jurisprudentiae Romanae 5 (1903), $1592 \mathrm{ff}$.

39. D.41.2.40.1; 46.6.6.

40. D.41.4.2.9; 43.3.1.3.

41. $D .11 .7 .43 ; 14.3 .17 .2 ; 19.5 .17 .2 ; 20.1 .12$.

42. D.17.2.26pr.; 29.2.68; 33.1.10.3; 40.7.2.4; 41.2.1.14; 41.2.32.2; 41.2.44.1; 41.4.2.9; 41.4.2.16; 43.1.2.1; 43.9.1.1; 45.1.4.2; 45.1.115.2.

43. D.13.5.5.9; 26.4.5.2; 35.3.3.10; 40.9.1. The remaining text is D.2.12.7.

44. When Papinian in D.17.2.81.2 says he interprets a pact ex aequitate, the same solution would follow from basic legal reasoning.

45. See, e.g., Alan Watson, Legal Origins and Legal Change 11ff. (1991); Spirit, $98 \mathrm{ff}$. 
"fine" solution to a socially practical one. And that they did not concern themselves much with what happened in court. We want to give a few examples of this approach, which is not too dissimilar from what we also find among the rabbis.

As a first example we choose the one instance known to us where a jurist, the great Quintus Mucius Scaevola (consul 95 B.C.), appeared in court. The case, the famous causa Curiana, involved the interpretation of a will that read "Let my son be my heir. If my son dies before reaching puberty, let M.' Curius be my heir."46 Quintus Mucius argued for a literal interpretation. M.' Curius was to be heir only on condition that the testator's son died before reaching puberty. But the testator never had a son therefore, argued Quintus Mucius, the condition failed, and Curius could not be heir. The reality of the testator's intention is defeated. And Scaevola's opponent, an orator not a jurist, won. Again when a testator provided "Let Cornelius and Maevius, whichever of them wishes, be my heir" and both wanted to be heir, (D.28.5.70(69)), Trebatius (circa 84 B.C. - A.D. 4) held that neither was to be heir. A more general failure of the jurists relates to the interpretation of the Twelve Tables' rules on intestate succession. The heirs were in order: first, sui heredes, that is, persons in the power of the deceased who became free from paternal power on his death; second, the agnatus proximus, the nearest agnate; third, the gentiles, members of the clan. 47 "The nearest agnate" was interpreted as that nearest agnate at the time the intestate died. If he himself died before accepting the inheritance, or if he refused it, the inheritance did not go to the next nearest agnate, but straight to the whole gens. ${ }^{48}$

A further example from succession is in $D .30 .63$ (Celsus, book 17 of Digest):

If the testator bequeathed all his female slaves and their offspring and one has died, Servius denies that her offspring is owed, because this was bequeathed by way of addition. I hold this to be false. This opinion accords with neither the words nor the wishes of the deceased.

No commentary on the artificial position of Servius is needed. 49 A particularly instructive text is $D .18 .1 .1 .1$ :

All buying and selling has its origin in exchange or barter. For there was once a time when no such thing as money existed and no such terms as "merchandise" and "price" were

46. The main sources are Cicero, de oratore $1.39 .180 ; 2.32 .43$; de inventione 2.42.122; Brutus 52.194ff; topica 10.42; pro Caecina 1853.

47. XII Tab. 5.4f.

48. For details see Alan Watson, The Law of Succession in the Later Roman Republic 176ff. (1974).

49. A further example from Servius could be adduced from $D .50 .16 .122$. 
known; rather did every man barter what was useless to him for that which was useful, according to the exigencies of his current needs; for it often happens that what one man has in plenty another lacks. But since it did not always and easily happen that when you had something which I wanted, I, for my part, had something that you were willing to accept, a material was selected which, being given a stable value by the state, avoided the problems of barter by providing a constant medium of exchange. That material, struck in due form by the mint, demonstrates its utility and title not by its substance as such but by its quantity, so that no longer are the things exchanged both called wares but one of them is termed the price. And today it is a matter for doubt whether one can talk of sale when no money passes, as when I give an outer garment to receive a tunic; Sabinus and Cassius hold such an exchange to be a sale, but Nerva and Proculus maintain that it is barter, not sale. Sabinus invokes as authority Homer who, in the lines which follow, relates that the army of the Greeks bought wine with bronze, iron, and slaves: "Then the long-haired Achaeans bought themselves wine, some with bronze $\left(\chi \alpha \lambda_{\kappa} \omega\right),{ }^{50}$ others with splendrous iron, oxhides, oxen themselves, or slaves." These lines, however, suggest barter not purchase, as also do the following: "And now Jupiter, son of Saturn, so deranged the mind of Glaucus that he exchanged his armor with Diomedes, son of Tydeus." Sabinus would have found more support for his view in what this poet says elsewhere: "They bought with their possessions." Still the view of Nerva and Proculus is the sounder one; for it is one thing to sell, another to buy; one person again is vendor and the other, purchaser; and, in the same way, the price is one thing, the object of sale, another; but, in exchange, one cannot discern which party is vendor and which, purchaser.

The second Homeric text has been cut short, and should conclude "gold for bronze $(\chi \alpha \lambda \kappa \omega)$." The point at issue between the Sabinians and the Proculians was a serious one. The rules for the contract of sale were relatively satisfactory, those for barter were not. The Sabinians, in this instance aware of realities, wished to include barter in sale: both parties could be regarded as buyers. But they could not use an argument from utility. Instead they produced an argument from Homer - no authority, but they could find no other where the purchase of wine for money, $\chi \alpha \lambda \kappa \omega$, was equated with its

50. The translation as "copper" in The Digest of Justinian (2d ed. 1988), by Alan Watson is inexact. The usual meaning of $\chi \alpha \lambda \kappa \omega$ in Homer is "bronze" which alone makes sense here: Cf. H.G. Liddell \& R. Scott, Greek English Lexicon 1974 (rev. 1996). 
purchase for oxen, slaves and so on. The Proculians, more concerned with legal purity, responded with another quotation from Homer. The Sabinians, they claimed, mistranslated $\chi \alpha \lambda k \omega$, which means not "money" but simply "bronze." The Proculians prevailed. ${ }^{51}$

Examples could be multiplied, but at this stage I would like to offer a few from book two of the famous textbook, the Institutes of Gaius, written around 161.52 Thus, G.2.196:

Only things belonging to the testator by Quiritary title can properly be legated by vindication. In the case of things reckoned by weight, number, or measure, such as wine, oil, corn, and money, it is held to be sufficient if they belong to the testator by Quiritary title at the time of his death. But all other things, it is held, are required to belong to him by Quiritary title at both times, namely that of his making the will and that of his death; otherwise the legacy is void.

"Quiritary title" means "at civil law." The second sentence of the text is formalistic in the extreme. The explanation is that the early will, the testamentum per aes et libram, involved the ceremony of mancipatio, a formal method of transferring ownership of important objects, and it conferred full civil law ownership at once. The doctrine, illogically but sensibly, was not originally applied in cases of succession: the recipient in the mancipatio did not become owner, and the named heir became owner of the inheritance only on the testator's death. Still, one consequence from archaic times was that in a legacy of the type called per vindicationem - where the legatee claimed as being already owner - only specific objects fully owned by the testator both at the making of his will and at his death went to the legatee. ${ }^{53}$ Again, there is G.2.238:

A legacy to an uncertain person is void. A person is considered uncertain of whom the testator had no certain conception, as where the legacy runs: 'To the first person who comes to my funeral let my heir pay 10,000 sesterces.' The law is the same if the legacy be to all in general 'whosoever shall come to my funeral'. In the same case is a legacy left thus: 'Let my heir pay 10,000 sesterces to whoever gives his daughter in marriage to my son.' Also, a legacy 'to the first persons designated consuls after the making of this will' is equally considered to be to uncertain persons. And in short there are many other cases of this kind. But a legacy to an uncertain person of a defined class is valid, for instance: 'To

51. See above all, David Daube, "The Three Quotations from Homer," in D.18.1.1.1.' now in David Daube, Collected Studies in Roman Law 341ff. (1991).

52. Cf. Francis de Zulueta, The Institutes of Gaius 2 (1953) at 5.

53. For details of the archaic testamentum per aes at libram see Alan Watson, Rome of the XII Tables: Persons and Property 61ff. (1975). 
that one of my kindred now living who is the first to come to my funeral let my heir pay 10,000 sesterces.'

The principle makes sense. But its application in the specific examples given by Gaius does not. Common sense would indicate that the principle should have been expressed so as to include within it the first examples given by Gaius.

Again, G.2.244:

It is a question whether we can validly legate to one who is in the potestas (power) of him whom we are instituting heir. Servius holds that the legacy is valid, but that it is avoided if, at the time when the legacies vest, the legatee is still in potestas, and that therefore the legacy is due alike if it be unconditional and the legatee cease in the testator's lifetime to be in the heir's potestas, or if it be conditional and the same happen before the condition is fulfilled. Sabinus and Cassius hold such a legacy to be valid if conditional but invalid if unconditional, arguing that though it is possible that the legatee may cease during the testator's lifetime to be in the postestas of the heir, the legacy must nevertheless be considered void, for the reason that it would be absurd that what would be invalid if the testator died immediately after the execution of the will should be valid just because he had a longer span of years. The authorities of the other school hold the legacy invalid even if conditional, on the ground that we can no more be conditionally debtors of those in our postestas than we can unconditionally.

The reasoning is that a person in potestate, in paternal power, can own nothing, and anything he acquires goes to his paterfamilias. The opinion of the old republican jurist, Servius (died 43 B.C.) ${ }^{54}$ seems sensible but imperial successors, Sabinus and Cassius, defeated the testator's intention, and even more so did the Proculians, the rivals of the other school.55

As is to be expected from a secular system there is less discussion of what appears to outsiders to be trivial situations. After all, secular law is not law as absolute truth. Still, such discussion is not lacking. For us, the most interesting examples are in D.33.9., a whole title of the Digest dedicated to legacies of "stores," penus. Such legacies seem to have been common. A fine discussion is in $D .33 .9 .3$ from the jurist Ulpian:

1. But Aristo notes that things which are not for eating and drinking are also included in the legacy, as, for instance, those things in which we are accustomed to eat things, such

54. Cf. Kunkel, Herkunft 25.

55. For other examples from Gaius, see, e.g., G.3.176; 3.179; 3.198. 
as oil, fish sauce, brine, honey, and other similar items. 2 . Admittedly, he says, if edible stores are legated, Labeo writes in the ninth book of his Posthumous Works that none of these things goes with the legacy, because we are accustomed not to eat these things but to eat other things by means of them. In the case of honey, Trebatius states the opposite, rightly, because we are accustomed to eat honey. But Proculus correctly writes that all these things are included, unless the testator's intention should appear otherwise. 3. Did he legate as eatables those things which we are accustomed to eat or also those things by means of which we eat other things? The latter should also be considered to be included in the legacy, unless the intention of the head of the household is shown to be otherwise. Certainly, honey always goes with edible stores, and not even Labeo denied that fish too, along with their brine, are included.

Aristo's ruling in fr. 1 that things not for eating or drinking but by which one eats or drinks, such as oil, fish sauce, brine, or honey, are included in the legacy of stores is surrealistic. Not so much the ruling as the very discussion. If the legacy is of olives, who is going to dispute whether the brine in which they are preserved is included? But the discussion then becomes fantastical in fr. 2. Aristo observes, apparently with approval, that if the legacy was not simply of "stores," but specifically of "foodstores," then Labeo was of the opinion that such things were not included. And Labeo (who died between A.D. 10 and 21) is one of the most respected jurists. ${ }^{56}$ But the issue was live even before: Trebatius (who probably died shortly after A.D. 4) would include honey (used in preserving fruits) in a legacy of "edible stores" because "we are accustomed to eat honey." And Aristo agrees. But then he goes on to agree with Proculus - the famous head of the Proculian school of jurists, active in the first century A.D. ${ }^{57}$ - that all such things would be included in the legacy unless it appeared that the testator thought otherwise. In fr. 3 Ulpian furthers the explanation.

In fact, the Roman jurists seem seldom to discuss actual factual situations. Very few such instances can be determined. Hypothetical situations were so much the rule that we have a text, D.3.5.29 (30), that begins "Ex facto quaerebatur," "A problem from real life." Such an opening is unthinkable if it were not that jurists habitually discussed hypothetical issues.

A type of discussion of trivia from another angle occurs when the subject matter is valuable but the legal institution would scarcely exist in practice. Central to the earliest Roman consensual partnership

56. Cf. Kunkel, Herkunft 114.

57. Cf. Kunkel, Herkunft $123 \mathrm{ff}$. 
was the societas omnium bonorum, a partnership of all the assets. ${ }^{58}$ This derived from the non-contractual ercto non cito which occurred when persons subject to the deceased's power became independent on his death, that is, primarily the children of the deceased. When they were in potestate they owned nothing hence the partnership was automatically of all their assets. The consensual partnership of all one's assets would not be a mercantile contract, except just possibly between brothers. It would be entered into when brothers or possibly very close friends operated a farm together. With the growth of Rome it seems very likely that it would become an extremely rare institution. Issues would very seldom arise in practice. Still, legal problems could be envisaged that could never arise from lesser partnerships. A prime example would be where the partners agreed that if a daughter of one partner married the dowry would come from the partnership funds. And a dowry from such a father could come from nowhere else! Thus, the provision of a dowry to the daughter of one partner was a charge on all the partners. Again, if one partner married, any dowry he received would be part of the partnership assets. The legal problems fascinated the jurists of the empire.

Thus, the jurist, Paul (active in the early third century) ${ }^{59}$ held that if a married partner was still married when the partnership ended, he would take the dowry (i.e. before the other assets were divided) since he was responsible for the expenses of the marriage. If on the other hand, the marriage was ended before the partnership, the husband who had to repay the dowry (traditionally in three annual payments) could take in advance of the other partners only on the day that each payment fell due. ${ }^{60}$ Still, Gaius active around the middle of the second century) ${ }^{61}$ tells us that if at the moment of dissolution of the partnership it is certain that not all of the dowry has to be returned the judge ought to divide it between the partners. ${ }^{62}$

As often, the great Papinian (executed in 212) ${ }^{63}$ discusses the most sophisticated issues. ${ }^{64}$ We will treat only one of these. A partner promised a dowry for his daughter, but died before payment. The marriage ended in divorce and the wife successfully sued her ex-husband for a formal release of the dotal obligation. When she brought the partnership action, could she take in advance from the partner-

58. See e.g., Franz Wieacker, Societas. Hausgemeinschaft und Erwerbsgesellschaft (1936); "Das Gesellschaftsverhältnis des klassischen Rechts," 69 Zeitschrift der Savigny-Stiftung 302ff. (rom. Abt.) (1952); Watson, "Consensual Societas between Romans and the Introduction of the Formulae," now in Alan Watson, Legal Origins and Legal Change 175ff. (1991).

59. Cf. Kunkel, Herkunft, $244 \mathrm{f}$.

60. D.17.2.65.16.

61. Cf. Kunkel, Herkunft, $186 \mathrm{ff}$.

62. D.17.2.66.

63. Cf. Kunkel, Herkunft, 224.

64. D. 17.2 .81 . 
ship assets the amount of the dowry? The answer was yes, because the agreement to pay dowries from the partnership was not unfair, especially if the wording was fitting for the daughters of both partners. It was irrelevant that only one partner had a daughter. ${ }^{65}$ Three great imperial jurists, Gaius, Papinian and Ulpian, avidly discussed the issues that could arise from a legal institution whose practical reality scarcely existed.

Finally in this section we would like to look once again at the horrifying senatus consultum Silanianum of A.D. 10. Among similar provisions it primarily declares that when a slave owner is murdered at home all the slaves who lived under the same roof are to be subjected to torture and then put to death. To the best of our knowledge this is the one important part of Roman slave law that was not accepted elsewhere. What is appalling is that the Roman jurists interpreted it as they did any other piece of law making. ${ }^{66}$ So ordinary did they consider it that they discuss it in the context of succession. After all, the murder of the master opened up his inheritance. Thus, D.29.4 is headed, "Where someone, passing over a will, takes possession of an inheritance on intestacy or in some other way." Our title is D.29.5, and significantly is entitled "The senatus consultum Silanianum and the senatus consultum Claudianum: those whose will may not be opened." The will of the murdered master was not to be opened until the slaves were executed in case he had freed some in his will. They would have become free and citizens at his death, hence could not be executed without trial, but they are treated as slaves! The next Digest title, D.29.6 is "If a person has prohibited someone from making a will or has compelled him to make one." Watson's point in the past has been that, horrifyingly, the jurists interpreted this decree according to their usual canons even when they contradicted the obvious purpose of the senatus consultum: to make slaves responsible for the safety of the owner. Thus, in The Spirit of Roman Law he concentrated on extreme instances where the senatus consultum was not applied. ${ }^{67}$ Professor Pennington, who has taken his knowledge of the senatus consultum from The Spirit of Roman $L a w$, and not from the original sources, suggests that the subsequent interpretation may have been intended to restrict the scope. ${ }^{68}$ Alas, no. There certainly was interpretation that restricted the scope, but equally there was wide interpretation. Thus, an owner included someone who had given his slave in pledge, ${ }^{69}$ or an heir from whom a slave was given as a legacy subject to a condition (even if the condition was fulfilled after the murder of this heir-owner), or even if the

65. D.17.2.81pr.

66. See already, Alan Watson, Roman Slave Law 134ff. (1987); Spirit, $165 \mathrm{ff}$.

67. Spirit, $165 \mathrm{ff}$.

68. Spirit, $1100 \mathrm{f}$.

69. D.29.5.1.3. 
slave was to become free under a condition from the previous testator..$^{70}$ One who had only a share in a slave was also owner. ${ }^{71}$ Children of the slave owner were owners for the purpose of the decree. ${ }^{72}$ And so it goes on. Ulpian held that the decree applied to an adopted son, but not to one given in adoption. ${ }^{73}$ It has to be remembered that at Rome adoption was a political act, and was not for the protection of infants. The son, given in adoption, who was murdered, but not covered by the senatus consultum, was living with his biological father!

\section{ISLAMIC LAW}

Joseph Schacht has commented that Islamic law represents an extreme case of a "jurists' law." " Schacht meant that Islamic law was shaped and developed by jurists who, for the most part, were not supported by the state. Schacht was also alluding to the highly formalistic and theoretical nature of Islamic law. According to Schacht Islamic law was developed by jurists employing casuistic methods of thinking, and who were disconnected from reality and practice. ${ }^{75}$ Therefore, Schacht concluded that Islamic law is not law at all but represented a unique phenomenon of juristic science. ${ }^{76}$

There is little doubt that Schacht is wrong. Several scholars have effectively refuted Schacht on historical grounds and theoretical grounds. ${ }^{77}$ Schacht ignored the fact that Islamic law was the product of a complex interaction between judges (qadis), jurisconsults (muftis) and the state. Muhammad Khalid Masud, Brinkley Messick and David Powers provide a helpful explanation as to various actors that helped shape Islamic law:

An important division of juristic labor marks the relation of the Shari'a, or Islamic law, to the concrete world of human affairs. Across time and space, two distinct categories of legal interpreters have stood at the meeting points of law and fact. The domain of legal procedure, including adversarial cases rules of evidence, binding judgments, and state enforcement, belongs to the judge ( $q \bar{a} d \bar{l})$; the issuance of

70. D.29.5.1.4.

71. D.29.5.1.6.

72. $D .29 .5 .1 .7$

73. D.29.5.1.9.

74. Joseph Schacht, An Introduction to Islamic Law 5, 209 (1984).

75. Introduction, 205.

76. Introduction, 200.

77. For example see Hallaq, "The Logic of Legal Reasoning in Religious and NonReligious Cultures: The Case of Islamic Law and the Common Law," 34 Cleveland State L. Rev. 79ff. (1985-86); "Was the Gate of Ijtihad Closed?," 16 Int'l J. of Middle East Studies 3ff. (1984). Also see Khaled Abou El Fadl, "Islamic Law and Muslim Minorities: The Juristic Discourse on Muslim Minorities from the Second/Eighth to the Eleventh/Seventeenth Centuries," 1 Islamic Law and Society 141ff. (1994). 
nonbinding advisory opinions (fatāwā, or fatwās) to an individual questioner (mustaft $\overline{\text { }}$ ), whether in connection with litigation or not, is the separate domain of the jurisconsult (mufti $)$. In their different venues, both qadis and muftis have specialized in handling the everyday traffic in conflicts and questions falling within the purview of the Shari'a.

Compared to qadis, muftis have received little attention in Western scholarship, in part because of the litigation-oriented expectations of many observers for whom the role of the jurisconsult is unfamiliar, and in part because, in many historical settings, the activity of the mufti was far less institutionalized than that of the qadi. Whereas qadis always were appointed, salaried officials who dispensed justice in public tribunals, many muftis operated privately and unobtrusively without any ties to the political authorities, while others were officially appointed. The significance of the work of the muftis - whether private or public - rests on the high degree of authority that could be carried by their opinions, which represent the closest Islamic equivalent to the familiar Anglo-American legal mechanism of case law precedent. ${ }^{78}$

Islamic law is the product of a complex dynamic between juristic opinions elicited by theory and material considerations. This points out another way in which Schacht was wrong. What Schacht described as a unique phenomenon in jurisprudence is not unique at all. Islamic law, like Roman and Jewish law, whether it dealt with material or theoretical issues, developed within a technical juristic culture with its own set of symbols and professional practices. In this culture jurists talked to jurists and the art of the trade was practiced for its own sake. Again, we emphasize that this did not mean that Muslim jurists were unaware of social realities or that they had no interest in such realities. It does mean that Muslim jurists, like other jurists, often engaged in the "hunt" for the most technically sound or correct answer, and that in doing so their primary fidelity was to the inherited practices of the juristic culture and not necessarily to social, ethical or political considerations. As such, Muslim jurists understood and responded to material considerations through the prism of the legal culture, and quite often the legal culture imposed its own distinct reality. For jurists the hunt is not simply a sport; it is their profession and life.

What Jacob Neusner said about Jewish law certainly holds true for Islamic law. Muslim jurists often take up questions that are internal to the system of jurisprudence under which they labored. The

78. Mohammed Khalid Masud, Brinkley Messick \& David S. Powers, Islamic Legal Interpretation $3 f$. (1996). 
discourses go on regarding questions that hardly seem urgent to outsiders and when we join the conversation of jurists we feel that we are joining a conversation long under way about topics that seem distant and obscure. Muslim jurists show little interest in explaining the context or in demonstrating the relevance of their discussions. It is as if one joins a debate between mathematicians who speak in an inaccessible language and who are not interested in explaining the relevance of their discussions to outsiders.

It bears emphasis that our point is not that Muslim jurists failed to respond to social or political realities. Our point is that the technique of the jurist often imposes its own logic and structure, and that Muslim jurists, like their Roman and Jewish counterparts, were often more interested in technical soundness and demonstrations of prowess than in the impact of certain decisions or social results. This is not because these jurists were oblivious to the social realities that surrounded them, but because legal culture imposes its own overwhelming reality.

Examples of technical distinctions that seem to make sense only within the specific culture of jurists are numerous. In these examples reality is firmly situated and understood from within the prism of legal culture. The law is the law not because it makes good sense or because of its desired social impact but because it is the product of the inherited legal culture. For instance, in the Shafi'i legal manual of Ahmad Ibn Naqib al-Misri (d. 769/1368) the author addresses which words uttered by a husband will effect a divorce. He explains that plain words will effect a divorce whether one intends a divorce by them or not but allusive words require a specific intent to divorce. Ibn Naqib states:

When the husband says, 'I divorce you,' or 'You are divorced,' the wife is divorced whether he has made the intention or not. . .Using allusive words to effect a divorce includes: the husband saying, 'You are now alone,' You are free,' 'You are separated,' 'You are parted,' 'You are no longer lawful to me,' 'Rejoin your kin,' 'You are footloose,' and the like; or if he says, "I am divorced from you,' or when he commissions his wife to pronounce the divorce, and she says, 'You are divorced'; or when someone asks, 'Do you have a wife?' and he says 'No' or when the husband writes words that effect the divorce no matter whether he is able or unable to speak at the time of writing or whether he is present or absent, or whether he writes in plain or allusive words. When one intends divorce by any of the above, the words effect it, but if one does not, they do not. But when a husband is asked, 
'Have you divorced your wife?' And he says, 'Yes,' then she is divorced even if he does not intend a divorce. ${ }^{79}$

It is not clear why saying "I am divorced from you," or commissioning ones wife to pronounce the divorce is considered allusive, while an affirmative response to "have you divorced your wife" is considered plain. It is also not clear why a writing is always considered allusive. These distinctions had little to do with social practices in the $8^{\text {th }} / 14^{\text {th }}$ century, but were the product of inherited distinctions developed in the specific legal culture. They make sense by reference to the practice of the juristic culture and not by reference to a social practice.

Often juristic discourse will reflect fidelity to consistency of doctrine and not necessarily to perceived understandings of social practices. For instance, the Prophet is reported to have declared that a triple divorce, as opposed to a single repudiation, is a particularly reprehensible form of divorce. ${ }^{80}$ Therefore, the Maliki jurist Sidi Khalil (d. 776/1374) in his influential legal manual states that a repudiation is considered triple if the husband declares, "You are repudiated by the most disgraceful, the worst, the dirtiest, the most hateful repudiation." A repudiation is only single where a husband says, "You are repudiated by the best repudiation" or "by an only and excellent repudiation."81 These formulas could hardly reflect social practices or understandings; it is unlikely that a husband would have told his wife that she is repudiated by an only and excellent repudiation. The important point, however, is that the frame of reference for the law is not social practice but consistency within the legal culture.

As background for the next example it should be noted that Muslims pray relatively long prayers five times a day, but they may shorten their prayers if they are traveling. The reason for this law is to alleviate hardship upon the traveler. Nevertheless, the Hanafi jurist Abu Bakr al-Haddad (d. 800/1397) states the following:

The intended destination is taken into account when the traveler makes his decision to travel. The stipulation of the intended destination is that the person says he is headed for such and such a place, but not that he is just going because he might go about the whole earth and not intend a particular place. Even though the distance between where he goes

79. Ahmad Ibn Naqib al-Misri, 'Umdat al-Salik 559f. (trans. Noah Ha Mim Keller 1991).

80. Under Islamic law a man and woman may marry and divorce up to three times without an intervening marriage. A triple divorce counts as three divorces on one occasion. The partners may not re-marry without the woman marrying a different man first.

81. F.H. Ruxton, Maliki Law: Mukhtasar of Siki Khalil 128 (1916). 
and where he started is a trip of three days, he does not qualify as a traveler. ${ }^{82}$

The rational behind the distinction of intending a specific place or traveling to an unknown destination does not seem to be socially based. The distinction, however, is based on the established practice in the Hanafi school of law. Early Hanafi precedents established that a legal license requires the formation of a specific intent and that doctrine persisted.

Frequently, a rule becomes firmly established but the original reasoning behind a rule is not preserved or recalled. Nevertheless, fidelity to the legal culture will preserve the rule and will result in efforts to explain its existence. For instance, the inherited Hanafi doctrine is that it is reprehensible to place baked bricks or wood on a gravesite but reeds are acceptable. Consequently, al-Haddad states:

It is said that baked brick is reprehensible only because it is made with fire and is therefore not auspicious. Therefore, rock and wood is not reprehensible. In the Hidayah it says that this determination of the principle is not sound. If fire is used in baking bricks, it is not the basis for the principle behind the reprehensibility because if it is customary to wash the corpse in hot water, fire was already used.

Al-Sarakhsi says the consideration in determining the principle is that it is said on account of the prohibition of building because that is what is in common between the baked brick and wood, for wood does not require the use of fire.

The Bukharis say baked brick is not reprehensible in our cities on account of it touching the corpse because of the ground's weakness so that Muhammad b. al-Fadl says if the coffin had been made of iron he sees no harm in it in this area. But it is appropriate to place an adobe brick on that which is touching the corpse.

Al-Timirtashi says baked brick is reprehensible only when it is touching the corpse. When it is on top of an adobe brick, it is not reprehensible, because it preserves the corpse from predatory animals and protects it from excavation. ${ }^{83}$

Although the Bukharis and Muhammad Ali al-Timritashi (d. 1004/ 1595) accommodate the social practices within their context but they do so within the technical requirements of the inherited doctrine, and, hence, the requirement of adobe bricks under the baked bricks.

Frequently, however, the rules are based on abstract hypotheticals that are unconnected to social imperatives. For instance, Khalil

82. Abu Bakr b. Ali al-Haddad, Jawharat Al-Nayyirah 1, 246 (1301) cited in and translated by Brannon W. Wheeler, Applying the Canon in Islam 190 (1996).

83. Al-Haddad, pp. 132f. cited in and translated by Wheeler, $200 \mathrm{f}$. 
states that a conditional repudiation will immediately take effect if it has been made subject to a condition concerning some past fact. For example, if a husband says, "I swear by my wife's repudiation, that if I had gone to Zayd yesterday, I would have killed him" the repudiation takes place immediately. Likewise, a repudiation shall immediately take effect if it is made conditional upon a future occurrence, at which, in all probability both parties will be present. For example, if a husband says, "You are divorced on the day of my death." The same holds true if the repudiation is made subject to a condition that is unknown to people or on an event undeterminable in the present. For instance, if a husband says, "You are repudiated if it pleases God" or "You are divorced if you become pregnant." Repudiation is also obligatory and immediate if it is made subject to a negative condition implying an unlawful act. For example, "You are divorced if I do not commit adultery." However if the husband says, "You are repudiated on the day Zayd arrives" or "You are repudiated if Zayd does not arrive." The repudiation is not immediate. ${ }^{84}$ The distinction between the examples of immediate and non-immediate divorces are not based on social demands or needs. They are based on hypothetical and abstract constructs, and on an accepted symbolic discourse within the legal culture.

The abstract reasoning developed in the legal culture will often invoke highly improbable situations that sometimes border on the absurd. For instance, Muslim jurists often discuss the consequences if a husband tells his wife, "You are repudiated by a quarter", "half" or "one-third a repudiation", or if a husband tells his wife, "You are repudiated one repudiation plus another," or "plus one half a repudiation," or if the husband tells his wife, "I divorce only one half of you" or "I divorce you three times minus three times." 85

Muslim jurists engaged in these hypotheticals partly to demonstrate the full range of the applicability of a rule. But, in addition, these abstractions demonstrated the competence of the jurist and his ability to find technically sound solutions to rather improbable situations.

The following example is from Ibn al-Muqri's ' $U$ mdat al-Salik:

If the husband says, 'You are divorced if God does not will it' she [the wife] is not divorced. . .If the husband says, 'If I divorce you it is as if I divorced you three times earlier,' it counts as one divorce. . .If the husband, tells his wife, 'If you enter that house, you are divorced,' but then she is subsequently divorced from him with a finalized divorce, after

84. Khalil, 130.

85. Khalil, 129; Ibn Muqri, 560. 
which he remarries her, and she then enters the house, then she is not divorced. ${ }^{86}$

In another example, Abd Allah Ibn Hanbal (d. 290/903) the son of the founder of the Hanbali school of law, Ahmad Ibn Hanbal (d. 241/ 855), reports the following exchange:

I asked my father about a man who says to his wife, 'You are divorced if I do not have intercourse with you today and you are divorced if I perform my ablutions after thaving had intercourse with] you today.' My father said, 'He may pray the afternoon prayer, then have intercourse with her, and when the sun goes down, he may perform his ablutions, as long as he did not mean by his statement if I perform my ablutions [specifically after having had] intercourse. ${ }^{\text {' } 7}$

Ibn Hanbal's response is technically correct, but it is also detached and objective and shows no interest in any social reality or implications.

Jurists do not only remove themselves from social realities by focusing on the technicalities and mechanics of law, but they will also assume that social behavior will conform to the mechanics of legal technique. As noted earlier, legal culture often acts as a prism through which the jurists' social understandings and expectations are formed. Jurists will often interpret the world through the lens imposed by the habit and practice of legal technique. Therefore, jurists will form understandings of concepts such as "causation" or "reasonableness" or characterize social tendencies but such understandings or characterizations are often a projection of legal technique. This often results in conceptualizations of social tendencies that seem rather odd, and these conceptualizations then become the basis for further rule making which is projected upon social practices. For example, the Hanafi jurist Ibn Umar al-Dabusi (d. 430/1038) states the following:

When something predominates in the existence of things, it becomes the precedent even if it is not found [there in all cases] like regarding the sleeper as having become impure from having sexual intercourse [during the night] because it [having sex] is predominate for people in this state and thus the sleeper is considered to have been affected even if he was not [in actuality]. ${ }^{88}$

86. Ibn Muqri, $560 \mathrm{ff}$.

87. Susan A. Spectorsky, (trans.), Chapters on Marriage and Divorce: Responses of Ibn Hanbal and ibn Rahwayn 126f. (1993).

88. Ali b. Umar al-Dabusi, Ta'sis al-Nazar (1320), cited in and translated by Wheeler, 148. 
Elsewhere, al-Dabusi explains the position of Abu Hanifa, the founder of the Hanafi school of law, regarding a special form of prayer performed when one is afraid of harm:

If a person prays on a boat, and is afraid for himself [that he might fall off], and so motions with his head [instead of bowing and prostrating], his prayer is permitted according to Abu Hanifah because the motioning of the head predominates on boats and so this becomes his legal state even if it was not the case [that he was afraid of falling off]. ${ }^{89}$

It is very likely that Abu Hanifa and al-Dabusi understood that not all people who are sleeping have had sex, and that not everyone on a boat is afraid of standing, bowing and prostrating on a boat. Furthermore, in all probability the personal experiences of these jurists confirmed the falsity of these assumptions regarding social practices. However this knowledge is largely irrelevant. What is relevant is the integrity of the legal method and the process by which these rules were produced.

Juristic fidelity to legal method and doctrine will often tenaciously preserve certain rules regardless of the evolving social circumstances. Therefore, one will find that within certain schools of thought specific legal doctrines will consistently survive, often for centuries at a time, regardless of whether these rules serve a social purpose or not. For instance, around the $3^{\text {rd }} / 9^{\text {th }}$ century the Hanafi school of thought developed the idea that a divorce obtained under duress is enforceable. Furthermore, the Hanafi school, contrary to other Islamic schools, adopted the notion that Islamic law's jurisdiction is territorial. The Hanafi's also adopted the atypical view that those who rebel against the government are iniquitous and sinners. The duress and jurisdictional rule was incessantly repeated by Hanafi jurists for twelve hundred years. The rule concerning rebels survived as accepted doctrine in the Hanafi school for about four hundred years. Around the $6^{\text {th }} / 12^{\text {th }}$ the specific rule regarding rebels was modified by some Hanafi jurists in a slow and gradual process. ${ }^{90}$ The persistence of legal doctrine is not only due to the impact of precedent on the legal mind. At times, certain inherited legal doctrines become part of the symbolic universe that identifies and distinguishes certain legal cultures. Abandoning or even questioning such legal doctrines would be seen by fellow jurists as unorthodox and, perhaps, as a form of heresy. It takes considerable creativity and bravery on the part of a jurist to challenge the established assumptions of a legal culture,

89. Wheeler, 148.

90. See Khaled Abou El Fadl, "The Islamic Law of Rebellion: The Rise and Development of the Juristic Discourses on Insurrection, Insurgency and Brigandage," (Ph.D. dissertation, 1999). 
and yet continue to identify oneself as a jurist from within the challenged tradition.

\section{Conclusions}

The Roman jurists, ancient rabbis and Muslim jurists were very different people. Above all, the rabbis and Muslim jurists were engaged on a search for law as truth. And the Roman jurists were much more obviously upper-class gentlemen. ${ }^{91}$ But the similarities are great. All three had a passion for legal interpretation. They delighted in discussing hypothetical cases. They chased after solutions by ways of reasoning devised by themselves. Practical utility, while present, was in the background. At times, to outsiders, their opinions seem outré, even callous, remote from reality. They have little interest in what actually happens in court: their texts do not smell of the courtroom even when they invent new devices. They do not seek to devise a system of law. Nor do they propose radical reform. They write for those interested in the same issues as themselves.

It may be suggested that the picture we have drawn is more appropriate to rabbis and Muslim jurists than to Roman jurists, to a search for truth rather than a commitment to social reality, but then the early history of Roman law must be brought into play. After the code of the Twelve Tables was promulgated in the middle of the fifth century B.C. a monopoly of interpretation was granted to the College of Pontiffs, the main state priestly body. And the Pontiffs chose one of their members each year to interpret this law. The main task of the Pontiffs was to preserve the right relations between the gods and the state or the leaders of the state. And their approach to this was that appropriate to the interpretation of religious law. Certain types of argument such as utility, fairness or economic advantage could not be expressed. And, naturally enough, the Pontiffs applied this approach to their interpretation of the Twelve Tables. ${ }^{92}$

Law is a conservative discipline. And when the Pontiffs lost the monopoly of interpretation, the jurists, their successors, continued the approach. This continued, of course with some modifications, to the end of the classical period of Roman law, traditionally dated around A.D. 235. The Mishnah and Shari'a were intended to be studied for their own sake. So, we believe, were the writings of the Roman jurists.

Subsequently in changed circumstances in Western Europe there are fewer signs of jurists being remote from reality. This may be we speculate - because law for them was not a hobby but a business, primarily in teaching and in consultation in actual disputes. Still,

91. We use that term to avoid being more precise.

92. See for more detail, Alan Watson, The State, Law and Religion: Pagan Rome 63ff. (1992). 
the legalistic, formalistic approach continued. Indeed, the approach was so prevalent in Western Europe that it is really superfluous to produce examples. ${ }^{93}$

93. But we should like to adduce two illustrations, both extreme, and of different kinds.

First, one from the great medieval jurist, Azo of Bologna (c. 1150 - 1230). A beginning student, Bernardus Dorna, used a verse of the Latin poet Ovid as an argument. Azo objected: Non licet allegare nisi Iustiniani leges, "It is not permitted to cite except the laws of Justinian:" Questiones 10, Scholaris quidam, in Quaestiones de Azo, Ernest Landsberg (ed.) 74 (1888). This is, of course, even more legalistic than some of the texts that we have seen from Roman jurists. Homer could be cited at Rome.

The second example is from modern law, the French code civil of 1804, art. 4, which in effect prohibits the citation of any authority except statute law. Of course, judges are aware of judicial precedent, juristic opinion and societal conditions, but the fact that these cannot be cited has consequences. 
